\title{
コンクリート中のピアノ線に熱処理を行なうことにより プレストレストコンクリートを造る方法*
}

\section{1. 緒言}

コンクリート中にすでに固着されているピフノ線に 熱処理を行なうことにより PC (prestressed concrete) そ造る方法として二つの方法を考えてみた。一つはマ ルテンサイト組織にしたピフノ線に電流を通し，電気 抵抗熱てピフノ線の温度を上昇させ，マルテンサイト 組織が狫きもどしにより起こす収縮を利用する方法で あり，または同じく電気抵抗熱でピフノ線を加熱し， 熟㱆張力でピアノ線に压縮応力を生じさせ，この応力 てピフノ線に正縮の塑性変形を起こさせて生じる収縮 を利用する方法である，以下ではこれらの考えの下で 行なった二つの実験のうち, 主として前者について述 ベる.

\section{2. 両端間の長さを一定に保たれた鋼材に熱処理 を行なうことにより引張応力を導入する方法}

第 1 図の上うに常温にて両端を固定された銅材を加 熱椧却するときに起こる鋼材内部の応力について考え てみる。銿材の温度を上昇していくと，その熱膨張に 相当する庄樎の熱応力が鋼材に生じるが，加熱温度が 低くてそれによる压縮応力が鋼材の弾性限以下であり， また加熱冾却の行程において鋼材の組織が変化して彭 張收縮が生じるようなことがない場合を考えると，加 熱冾却にしたがって可逆的な熱応力が鋼材に生じるだ けであり，常温まで命却したときには鋼材に応力は残 らない.

加熱冷却の行程で鋼材の組織に変化が起こり，その ために膨張収縮が起こる場合には，加熱冷却後常温に もどしたときにはその膨張または収縮量に相当するだ

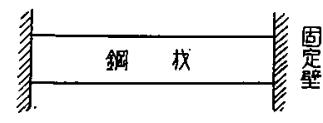

第 1 図一定距離に保たれた壁に両端を 固定された鋼材

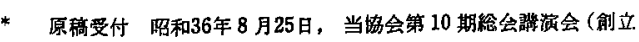

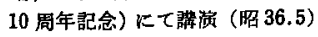

* 正員 工菜技術院大阪工莱技術訊験所
}

黒 田 寿 紀** 近 藤 春 樹**

けの圧縮あるいは引張応力が生じることになる。両端 を固定していない自由に膨張収樎のできるマルテンサ イト組織化したピアノ線を $300^{\circ} \mathrm{C}$ ま加熱した後冷却 したときの温度と長さの関係を一例として第 2 図に示 す：ピアノ線は加熱冷却するにしたがって嘘張収縮を しているほかに，金属組織が変化することによっても 著しい収縮を起こしており，常温に冷却した後ではも との長さより著しく短くなっていることがかかる．加 热冷却の前後で両端の長さが一定に保たれているとす ると、ピアノ線にはこの収縮分だけの引張応力が生じ るはずである。

加熱冷却の過程で組織の変化を生じない場合でも加 熱温度を充分高くしていくと，正縮の熱応力が充分高 くなっていく一方, 鋼材の王縮弾性限はどんどん降下 してくるため，ついには鋼材は圧縮の塑性変形をする ようになる。塑性変形の起こった鋼材の温度をさらに 上昇していくと塑性変形量はどんどん上昇していくが， 压縮弹性限はますます降下していくためそのときの圧 縮応力は減少していく，この圧縮の塑性变形によりそ

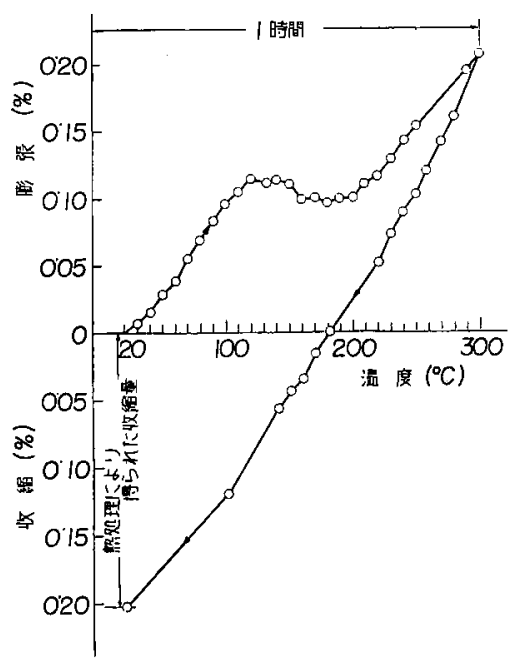

第2図 マルテンサイト組織化したピフノ線 の熱処理による膨張収縮 
の分だけ鋼材は長さとの垂直方向にふくれることにな る。一度加熱時に王縮の塑性変形をした鋼材怯，その 温度より椧却していくと常温以上の温度で応力が零に なり，常温では引張応力が残留することになる。

実際鋼村を加熱する場合には，その組織の変化の様 子も多種多样であるだろうし，組織の変化と塑性変形 が同時に生じる場合もあるだろうし，生ずる引張応力 により鋼材が引張りの塑性変形を受けたり町断したり する場合もあるので上記のように簡単ではないことに なる。なおここで使用した応力ということばはテン ソルで表わされる笽密なものではなくて，長さの方向 の主応力の平均值という意味である。

3. コンクリート中のピアノ線を加熱したと きに起こる現象についての考察

コンクリート中に固定されたピフノ線をたとえば 電気抵抗熱で加熱した後放冷すると，いかなる現象が 起こるか考えてみる，まず第一に，ピアノ線とコンク リートがすべることが考えられ，これがいちばん重要 なことであるが一応考えないことにしておく，そうす
ると加熱放冷の前後においてコンクリートの長さすす なわちピフノ楾の長さは変化しないと考えられるので, マルテンサイト組織にしたピアノ線を使用した場合に は上述のように組織の変化に上る引張応力を熱処理に より導入できるはずである。

次に組織の変化の起こらない場合を考える。まず， ピフノ線はその長さと垂直方向には穆張収縮が可能て あると考える（これに対しては後述のような対策を考

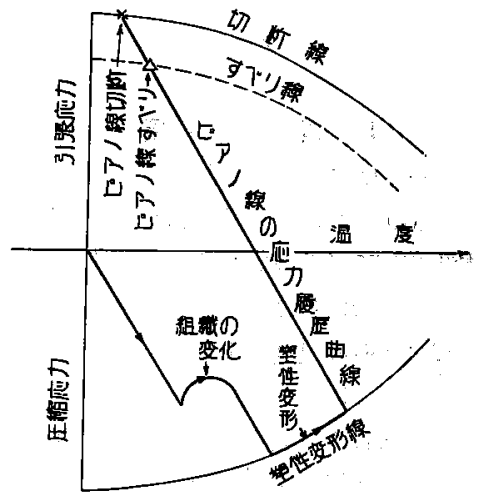

\begin{tabular}{|c|c|c|c|c|}
\hline 結果 & $\begin{array}{c}a \\
\text { 組䥫の变化 }\end{array}$ & 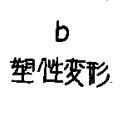 & $\begin{array}{c}c \\
\text { 組絏の变化 } \\
+ \text { 塑迹变形 }\end{array}$ & 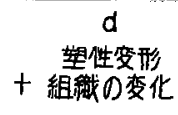 \\
\hline 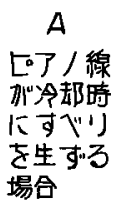 & & & & \\
\hline 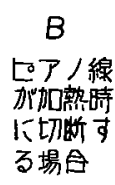 & & & & \\
\hline 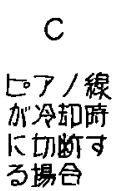 & & & & \\
\hline 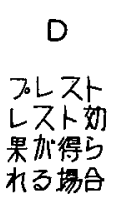 & & & & \\
\hline
\end{tabular}

第 3 図 熱処理時におけるコンクリート中のピアノ線の応力履歴 
えたが必ずしも必要ではなかった)，そうするとピフ 線住自身が電気抵抗熱で発熱するため充分早く温度 上昇を起こさせることができるが，コンクリートはピ アノ蜍からの熱伝導のみにより温度が上昇するためそ れほど急には温度が上昇せず, ピアノ線の急な温度上 昇によりコンクリートとピアノ線の間に著しい温度差 を生じさせることができるため，ピアノ線とコンクリ 一トの熱膨張係数をほほ等しいと考えても，上述のよ うに塑性変形により引張応力を導大できるはずである。 コンクリートとピアノ線との間のすべりも考えて， ピフノ線に生じる応力履歴を考えてみると第 3 図のよ うないろいろな場合が得られる。第 3 図に批いて組織 の変化は加熱時に収縮が 1 回起こる場合だけを考えて ある．図の横軸はピアノ線の温度を，縦軸はピアノ線 に生じる応力で上側に引張応力をとってある. 矢印の つけた太線は過熱放冷のときのピアノ線に生じる応力 履歴を示す線である，点線仙仮想したすべり線で応力 履歷線がこれと交わると，そこで( $($ 点で示す)ピア， 線がコンクリートに対してすべることを表わす，下側 および上側の細い曲線はそれぞれ王縮塑性変形曲線と 引張破断曲線を表わし，応力履歷曲線がこれらと交わ ると，ピフノ線が圧縮の塑性变形を受けたり，引張破 断をしたり(メ点で示す)することを示している。この 両曲楾はそれで表わされる応力がいずれる温度の上昇 とともに小さくなることを考えて描いてある。図の $A$ は放冾中にすべりが起こる場合を示し，Bは加熱中に でも，組織の変化により充分大きな引張応力を生じて 切断する場合を考虑して描いてあり，組織の変化がな ければ起こらない，Cは放冾中に切断する場合で，組 織の変化によっても，塑性変形によっても起こる．D は都合よくプレストレス尊入ができる場合で，得られ た引張応力は○印で示してある。また $a は$ は組織の変化 のみ，bは縮の塑性変形のみが生じる場合であり， $c, d$ はこの両者が相次いで生じる場合である.ピフ ノ線の加熱によりコンクートにプレストレスを導入す ることができるのはDの場合だけであるが，そのうち 簡単な $D_{a}, D_{b}$ に近い状態を示すと考方る実駩を行な った．しかし実験中には，ピアノ線が放冷中に切断し てCと考えられる場合もあったし，放椧中にすべりを 生じて Aと考えられる場合もあった。ただしBの場合 には一度も出合わなかった。

\section{4. 組織の変化を利用して PC を造る実験方法}

ピアノ線とホポルトランドセメント1砂 2 の割合で のモルタルで第 4 図に示すような曲げ試験片を 2 個造 った. 使用したピアノ線は直径 $2 \mathrm{~mm}$, 引張強度 200 $\mathrm{kg} / \mathrm{mm}^{2}$ ，化学成分は第 1 表に示すとおりのもの党, 電気抵抗熱で約 $800^{\circ} \mathrm{C}$ に数分間加熱してから水冷して マルテンサイト組織化したもので，第 2 図の曲楾はこ

昭和 37 年 4 月
のピアノ線を使用して求めたものである。ピフノ線の 両端が上方に曲げてあるのは，次にピフノ線を熱処理 するときに考えられるコンクリートとピフノ線の間の すへりのおそれに対応するためであり，曲げ試臨片の 上下に抵抗線型ひずみゲージ添付してあるのは，上 下面におけるコンクリートの收縮量からでもプレスト レスカを測定するためである。

2 個の試験片のうちの 1 個につき，マルテンサイト 組織化したピフノ線に電流を通して約 $300^{\circ} \mathrm{C} に$ 加熱し てマルテンサイト組織を分解し，そのときに生じる収 縮によりコンクリートを楴めつける，加熱温度を 300 ${ }^{\circ} \mathrm{C}$ と定めたのは，あまり温度が高いと正縮の塑性変 形による影響がでると考えたからである，加熱には交 流変圧器による電流を通したが，コンクリート内部に あるピアノ線の温度を直接測定することは困難である ため，まず 0.8Vの低電圧で電流を通してピフノ線の 常温における電気抵抗を測定しておき，次に電圧を上 昇して電気抵抗が初めの約 $2 \cdot 5$ 倍になるまでピア，線 党加熱して大体 $300^{\circ} \mathrm{C}$ 前後の温度が得られているもの とした．この加樊中に, ピフノ線のコンクリート中の 部分は空中にでている部分に比べて著しく温度の上昇 速度が幄いため，コンクリート中の部分が適温に上昇 するまでに，空中にでている部分が過熱して切断した り，あるいは抵抗変化からの温度測定を不正確にした りするため，その部分をコンプレッサーで空冷して温 度上昇の起こらないように注意した。次で放冾してプ レストレス導入を行なった。

抵抗線型ひずみ計によるひずみ量の測定では，加熱 直後にはピアノ線やコンクリートは熱膨張をするし， びずみゲージの温度も変化して真のプレストレスの測 定を不可能にする。またそれ以外のときにも気温の変 化とか，コンクリートの乾燥収縮とか，ゲーシ接着剤 の変化とか，ひずみ計の電池の消耗等のため，ひずみ 計の指示は変化するので，加熱処理を行なう充分前後

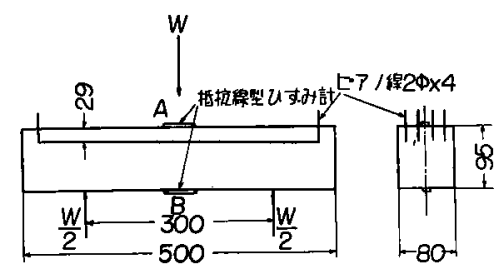

第4図曲 げ試験 片

第 1 表 ピアノ線の分析値（\%)

\begin{tabular}{c|c|c|c|c|c}
\hline $\mathrm{C}$ & $\mathrm{Si}$ & $\mathrm{Mn}$ & $\mathrm{P}$ & $\mathrm{S}$ & $\mathrm{Cu}$ \\
\hline 0.82 & 0.20 & 0.49 & 0.15 & 0.014 & 0.09 \\
\hline
\end{tabular}


にわたってひずみ計の指示を測定しておき，加熱前の ひずみ变化の傾向曲線と，加䱈後におちついたひずみ 量との食い臬い量から，鋼のヤング率を $2 \times 10^{6} \mathrm{~kg} /$ $\mathrm{cm}^{2}$ 、コンクリートのそれを $2 \times 10^{5} \mathrm{~kg} / \mathrm{cm}^{2}$ として組 織の変化に基困するプレストレスカを算出した，

曲げ試験はプレストレス導入をした試験片と，そう でないもう一つの試験片につきインントロン社の引 張陚験機を使用して，スパン $30 \mathrm{~cm}$, 負荷速度 0.05 $\mathrm{cm} / \mathrm{min}$ で行ない, コンクリートにき裂を生じる曲げ モーメントの差から，

$$
P=\left(M_{2}-M_{1}\right) /(Z / A+e)
$$

の関係式でプレストレスカ $P$ を測定した。この式は

$$
P / A+(P e) / Z-M_{2} / Z=f_{c}=-M_{1} / Z
$$

より誘導したものでここで $f_{\mathrm{c}}$ はコンクリートのき 裂応力を， $e$ 住偏心距離を， $A, Z$ はそれぞれコンク リート断面の断面積と断面二次モーメントを， $M_{2}, M_{1}$ はそれぞれプレストレス尊入した試酫片としない試験 片にき裂を生じるに必要な曲げモーメントを示す，

だいたい上に述べたような実験を 5 回行なった，だ たいたといったのは，できかがった曲げ試験片の形に 少しの差があったり，ピフノ線の偏心距離が必ずしも そろわなかったからである。

\section{5. 実 験 結 果}

通電前後にひずみ計の示した值の一例を示すと第 5 図のとおりである、図でCゲーシとは熱処理を行なわ

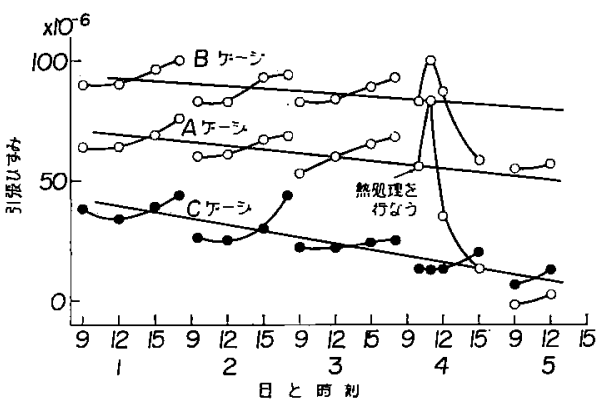

第 5 図 コンクリート中のピアノ線の熱処理 前後におけるひずみ計指示の経過

\begin{tabular}{|c|c|c|c|c|}
\hline \multirow{2}{*}{ 試跧番号 } & \multicolumn{2}{|c|}{ ひずみ計使用による方法 } & \multicolumn{2}{|c|}{ 陆げ陚験の比较による方法 } \\
\hline & $\begin{array}{l}\text { ブレストレ } \\
\text { ス吕 } \\
(\mathrm{kg})\end{array}$ & 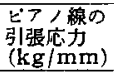 & $\begin{array}{l}\text { ブレストレ } \\
\text { ス吕 } \\
(\mathrm{kg})\end{array}$ & 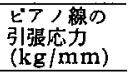 \\
\hline 1 & 530 & 42 & 540 & 43 \\
\hline 2 & 3800 & 240 & 483 & 31 \\
\hline 3 & 560 & 36 & 370 & 24 \\
\hline 4 & 1560 & 83 & 500 & 26 \\
\hline 5 & 552 & 44 & 515 & 41 \\
\hline
\end{tabular}

第 2 表 新しい方法に上り導入したプレストレスカ
ないほうの曲げ試験片に添付したひずみダージであり， A，B ゲージは第 4 図に示すように熱処理を行なうほ うの曲げ試験片に添付したひずみゲージである．通電 の直後において熱処理したテストピースのはうのひず み計の指示が増加しているのは，コンクリートの熱憉 張，ひずみゲージの温度上开等によるものと思われる。 ひずみ計の測定より得られたプレストレスカが曲げ試 駼の比较結果より得られた値とともに第 2 表に示して ある，第 2 表によると，ひずみ計による測定では，熱 処理により異常に大きなプレストレスカを示している ものがある。このようなことは予備的実験の場合にも しばしばあつたことで，その理由はよくわからないが， このことはひずみ計による測定結果はあをり参考にな らないことを示しているのかもしれない。

比較曲げ試駖よりの結果はばらついているが，これ はコンクリートのき裂強度が必ずしも同一でないこと から当然のことであろう。

以上の結果よりわかるようにこのような方法によ りピフノ線には約 $40 \mathrm{~kg} / \mathrm{mm}^{2}$ の引張俯力が尊入でき るものと考えられる。このことは第 2 図よりわかるよ

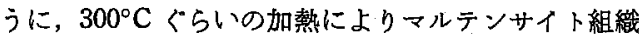
起変化させて求められる収縮量は約 $2 \%$ ありり，した がって，コンクリートの収縮がないと仮定しても尊太 できる応力が $42 \mathrm{~kg} / \mathrm{mm}^{2}$ であることに一致しており， これ以上の応力が導入できないことはいたしかたのな いことである。ピアノ線とコンクリートのすべりは， 少なくとも加熱放冷のときに起こったことはなかった し，曲げ試験のとさにも必ずしも起こるとはかぎらな かったまたピアノ線に接するコンクリートは加整温 度が大して高くないこと，加熱時間が短いこと等のた め，ほとんど変化を受けていない上うである。したが って，各種の条件を適当に選べば以上に述へた方法に より充分有用な結果が得られるものと思われる. 熱処 理後のピアノ線のち張強度は相当劣化しているが，40 $\mathrm{kg} / \mathrm{mm}^{2}$ 程度の導入応力に対しては充分である。

\section{6. 塑性変形を利用して PC を造る方法}

烧入れの行なってないピフノ線を使用して，第 4 図 のような二つの曲げ試験片を造り，曲げ試験結果の比 較でプレストレスカを測定することにした，加熱時に ピアノ線の長さの方向に生じる圧縮応力により塑性変 形を生じやすくするように，第 6 図のようにピスノ線 のまわりに木綿系を螺線状に巻いて使用し，長さの方

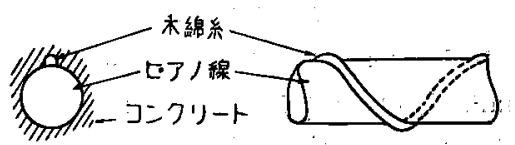

第6図 木綿系を巻いたピフノ楾 
向の圧縮塑性変形分を逃げやすいように考慮した。一 つの曲げ試験片のピフノ線に電流を通し，その電気抵 抗が常温のそれの約 4 倍になるように加熱して $700^{\circ} \mathrm{C}$ 前後の温度が得られるようにしたが，前の方法による 場合よりも空中にでている部分の過熱が激しくして， 空気を吹きつけるぐらいではコンクーリ中のピアノ楾 の盜度が上昇する前に空中の部分が焼き切れるので， 試験片全体を水中に入れて嶕処理を行なった。この場 合には前の方法による場合よりも，ピフノ線あるいは その付近のコンクリートの效膨張量が大きいため, 加 熱中にコンクリートにき裂を生じることが多く，充分 コンクリートが固まって強度が得られてから使用する 必要があった，ピアノ線に充分な応力が導入できてい ることは，放冾の過程で通電停止後 2,3 秒のときで ピアノ線が相当冷却していると考えられるときに，引 張試験の破断時のような音をだしてピアノ線が切断す ることや，著しい音をだしてすべりを生じることがし ばしば起こったことより推察される。

ピアノ楾に得られた引張応力の一例老曲げ試験結果 の比較上り算出してみると $38 \mathrm{~kg} / \mathrm{mm}^{2}$ であり, 熱処 理後のピアノ線の強度は $90 \mathrm{~kg} / \mathrm{mm}^{2}$ であった。この 場合, 特に心配されるのはコンクリートとピアノ線の 接着力であり，放冷過程中にしばしばすべりを生じた こともあったが，好都合に得られた製品では，曲げ試 験後破断してピアノ線とコンクリートの接着状況を調 ヘてみると，ピアノ線の表面には厚い互酸化鉄（X線 測定による) の膜が生じており，ピアノ線とコンクリ 一トはきわめてよく密着してい心，一方，すべりを生 じたと光の製品ではこのような膜は見つけられなかっ た.このようないろいろな場合が生じたのは, コンク リートのばらつきや，加熱条件のばらつきによるもの と思われるが，適当な条件で正しく行なった場合には 充分な結果が得られるものと思われる。ピアノ線に接 するコンクリートの部分は相当高温になると考えられ るので，なんらかの変化を受けることが考えられるが， 熱処理後破断して肉眼でみたぐらいではなんらの変化 は認められなかった。

\section{7. 結 言}

コンクリート中に固定されたピフノ線に電流を通し て PC を造る二つの方法につき二, 三の実騟を行なっ た結果，いずれの方法によってもプレストレスを導入 できることがわかった．前者の方法はピアノ線に導入
できる応力は現在行なわれている方法による導入応力 の半分以下で充分でないが，加熱温度が低いため操作 が容易であることが特徵であり，金属材料の研究によ ってはもっと収縮の大きい組織の変化を利用してプレ ストレスカを上昇できる希望がある，後者の方法では コンクリート強度の上昇により，加熱中にコンクリー トにき裂を生じなければ充分大きなプレストレス力を 与えることができるはずである、いずれの方法も加熱 操作により金属材料の強度を务化してしまうのが欠点 であるが，このことはそれほど上質な金属材料の使用 が無意味であることを示している。また，すべりを生 じることも大きな心配の一つであるが，これに対して は有刺鋼線やより(然)鋼線の使用が考えられる。ピア ノ線を収縮させるための加熱に交流变圧器を使用した がこれはピアノ線の長さが長くなればなるほど大容 量の電源が必要なことを意味している，高周波電流を 使用する誘導加熱等の方法により，部分ずつ加熱して いく方向も考えられるかもしれない，あるいは中性子 線放射その他の物理的方法の使用によって金属材料に 収縮を起こす方法があれば，それらの方法も利用でき るはずである。

以上に述べた方法は，たとえ導入できる鋼材の引張 応力は小さくても，容易にしかも第 $7 ， 8$ 図のような 曲りくねった鉄筋にもそのまま引張応力を与えること ができるので，応用の道もきわめて広いことと考えて いる.

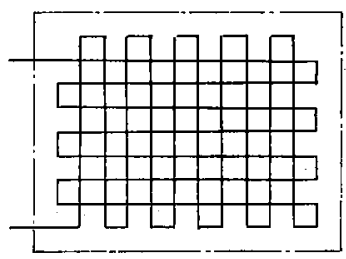

第7図 板を強化するためのピフノ線の形

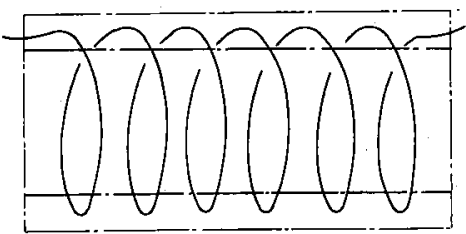

第 8 図 管を強化するためのピフノ線の形 